\title{
Environmental factors shaping ungulate abundances in Poland
}

\author{
Tomasz Borowik • Thomas Cornulier • \\ Bogumila Jędrzejewska
}

Received: 27 September 2012 / Accepted: 16 May 2013 / Published online: 29 June 2013

(C) The Author(s) 2013. This article is published with open access at Springerlink.com

\begin{abstract}
Population densities of large herbivores are determined by the diverse effects of density-dependent and independent environmental factors. In this study, we used the official 1998-2003 inventory data on ungulate numbers from 462 forest districts and 23 national parks across Poland to determine the roles of various environmental factors in shaping country-wide spatial patterns of ungulate abundances. Spatially explicit generalized additive mixed models showed that different sets of environmental variables explained 39 to $50 \%$ of the variation in red deer Cervus elaphus, wild boar Sus scrofa, and roe deer Capreolus capreolus abundances. For all of the studied species, low forest cover and the mean January temperature were the most important factors limiting their numbers. Woodland cover above $40-50 \%$ held the highest densities for these species. Wild boar and roe deer were more numerous in deciduous or mixed woodlands within a matrix of arable land. Furthermore, we found significant positive effects of marshes and water bodies on wild boar abundances. A juxtaposition of obtained results with ongoing environmental changes (global warming, increase in forest cover) may indicate future growth in ungulate distributions and numbers.
\end{abstract}

Keywords Forest cover · January temperature - Arable land · Red deer $\cdot$ Roe deer $\cdot$ Wild boar

Communicated by: Matthew W. Hayward

T. Borowik $(\square) \cdot$ T. Cornulier $\cdot$ B. Jędrzejewska

Mammal Research Institute, Polish Academy of Science,

ul. Waszkiewicza 1,

17-230 Białowieża, Poland

e-mail: tborowik@ibs.bialowieza.pl

T. Cornulier

Institute for Biological and Environmental Sciences,

University of Aberdeen, Tillydrone Avenue,

Aberdeen AB24 2TZ, UK

\section{Introduction}

Ungulate population dynamics are shaped by densitydependent and independent factors (Saether 1997; Jędrzejewska and Jędrzejewski 2005; Brown 2011). These influence the population vital rates, which often leads to changes in population numbers (Jorgenson et al. 1993; Willisch et al. 2013). In temperate environments and at high population densities, intraspecific competition for food increases winter mortality and reduces fecundity rate (CluttonBrock et al. 1987a; Capurro et al. 1997; Coulson et al. 2000). Furthermore, population density influences the age of maturity and pregnancy rate among females (Clutton-Brock et al. 1985, 1987b). Among density-independent factors, weather conditions have significant and multidirectional effects on ungulate demography, operating mainly through changes in mortality or indirectly through the quantity and quality of food (Post and Stenseth 1999; Hone and Clutton-Brock 2007). For example, harsh winter conditions affected the survival rate of Soay sheep (Milner et al. 1999; Coulson et al. 2001), red deer (Cervus elaphus; Forchhammer et al. 1998), and roe deer (Capreolus capreolus; Gaillard et al. 1993), and they shaped recruitment in mountain-dwelling woodland caribou (Rangifer tarandus caribou; Hegel et al. 2010). Autumn weather influenced reproduction rates of female white-tailed deer (Odocoileus virginianus), while spring weather conditions affected their reproductive success (Simard et al. 2010). In red deer, the weight at birth was influenced by rainfall in winter and temperature in spring (Sims et al. 2007). The annual variations in weather influenced the time and rate of plant green-up which affected the juvenile growth of bighorn sheep (Ovis canadensis) and mountain goat (Oreamnos americanus), the survival of bighorn sheep and Alpine ibex (Capra ibex; Pettorelli et al. 2007), and the age of first reproduction in red deer (Langvatn et al. 1996).

Ungulates in many regions are subjected to hunting and predation. The effects of predation on ungulate density have 
been a controversial issue. Several studies confirm a density-dependent regulatory role of predation (Ballard and Miller 1990; Messier 1994), and others show predation as a density-independent limiting factor (Larsen et al. 1989; Boutin 1992; Jędrzejewska et al. 1997). Interestingly, predators appear to have diverse effects on different ungulate species (higher for small-sized ungulates) or the same species at different density levels (Hayes et al. 2003; Jędrzejewska and Jędrzejewski 2005).

Whereas most of the above-mentioned studies explored the effects of density-dependent and independent factors on ungulate population at a local scale, broad-scale countrywide analyses of factors shaping variation in ungulate density are rare. Our study aims to fill this gap. Based on official data on numbers of three of the most abundant ungulates in Poland (red deer, roe deer, and wild boar (Sus scrofa)), we (1) evaluate which environmental factors correlate with spatial variation in ungulate densities, (2) determine the significance of the relationships between explanatory variables and ungulate abundances, and (3) discuss the applicability of the obtained results in predicting future demographic and distribution trends for ungulates.

\section{Study area}

Annual game censuses cover the whole of Poland $\left(311,904 \mathrm{~km}^{2}, 49^{\circ} 00^{\prime}-54^{\circ} 50^{\prime} \mathrm{N}, 1^{\circ} 08^{\prime}-24^{\circ} 09^{\prime} \mathrm{E}\right)$. Poland is a largely lowland country with plains $(<300 \mathrm{~m}$ a.s.l. $)$ constituting $91 \%$ of the area. Uplands (301-500 m a.s.l.) cover $6 \%$ and mountains (500-2,499 m a.s.1.) $3 \%$ of the country. Geographical regions change with latitude: from lowlands in northern and central Poland to uplands and mountains in the south. Poland is located in the temperate climate zone with a transitional character (Atlantic influences in the west and continental in the east). The mean annual temperatures are highest in south-western and southeastern Poland $\left(8.5^{\circ} \mathrm{C}\right)$ and lowest in the north-east $\left(6^{\circ} \mathrm{C}\right)$. The mean January temperature varies from $-8{ }^{\circ} \mathrm{C}$ in the mountains to $-1{ }^{\circ} \mathrm{C}$ in the western part of the country. The mean temperature of July ranges from $10{ }^{\circ} \mathrm{C}$ in the mountains to $16.5{ }^{\circ} \mathrm{C}$ at the Baltic Sea coast and $19{ }^{\circ} \mathrm{C}$ in the south west. Annual precipitation is $500-650 \mathrm{~mm}$ in the lowlands and 1,200-1,500 $\mathrm{mm}$ in the mountains (Central Statistical Office 2011a).

Nearly $99 \%$ of Poland lies in the Baltic Basin (including $56 \%$ in the Vistula River Basin and $34 \%$ in the Odra River Basin). Almost $1 \%$ of the country is covered by lakes $>0.01 \mathrm{~km}^{2}(n=9,300)$. The majority are glacial lakes occurring in the Masurian and Pomerania Lakelands in the north of the country.

The mean human population density is 122 inhabitants $/ \mathrm{km}^{2}$ and varies from 20 in north-western and north-eastern Poland to
500 inhabitants $/ \mathrm{km}^{2}$ in Upper Silesia, SW Poland (Central Statistical Office 2011b). The mean density of roads (motorways) was $80.7 \mathrm{~km} / 100 \mathrm{~km}^{2}$ in 2004. Around $60 \%$ of Poland's area is covered by farmlands with a predominance of arable lands (90\% of farmlands) and smaller shares of meadows and orchards.

Forests cover $29 \%$ of the country (Fig. 1). The majority of forests are coniferous stands dominated by Scots pine (Pinus sylvestris, $60 \%$ of forest area) and Norway spruce (Picea abies, $6 \%$ ). Deciduous and mixed forest consisting of oak (Quercus robur and Quercus petraea), ash (Fraxinus excelsior), maple (Acer platanoides and Acer pseudoplatanus), beech (Fagus sylvatica), hornbeam (Carpinus betulus), birch (Betula verrucosa and Betula pubescens), and alder (Alnus glutinosa) constitute about $25 \%$ of all forest land (Central Statistical Office 2011c). About $98 \%$ of woodlands are commercial stands and only $2 \%$ are national parks and reserves. Most of the commercial stands are State Forests $(83 \%)$, the rest remain private property. The State Forests are divided into 439 forest districts (in 2003). Their size varies from 89 to $2,501 \mathrm{~km}^{2}\left(\bar{x}=701 \mathrm{~km}^{2}, \mathrm{SD}=417.8 \mathrm{~km}^{2}\right)$ depending on forest cover (forest district size is inversely proportional to the amount of forest cover). Among 23 national parks, Biebrza National Park (NP) is the largest $\left(592 \mathrm{~km}^{2}\right)$, whereas Ojców $\mathrm{NP}$ is the smallest $\left(22 \mathrm{~km}^{2}\right)\left(\bar{x}=136.8 \mathrm{~km}^{2}, \mathrm{SD}=132.6 \mathrm{~km}^{2}\right.$; Central Statistical Office 2011c).

Three native species of ungulates occur throughout Poland: red deer, wild boar, and roe deer. In the northeastern and eastern parts of the country, moose (Alces alces) and a few isolated populations of European bison (Bison bonasus) also occur. An endangered population of chamois (Rupicapra rupicapra) persists in the Tatra Mountains

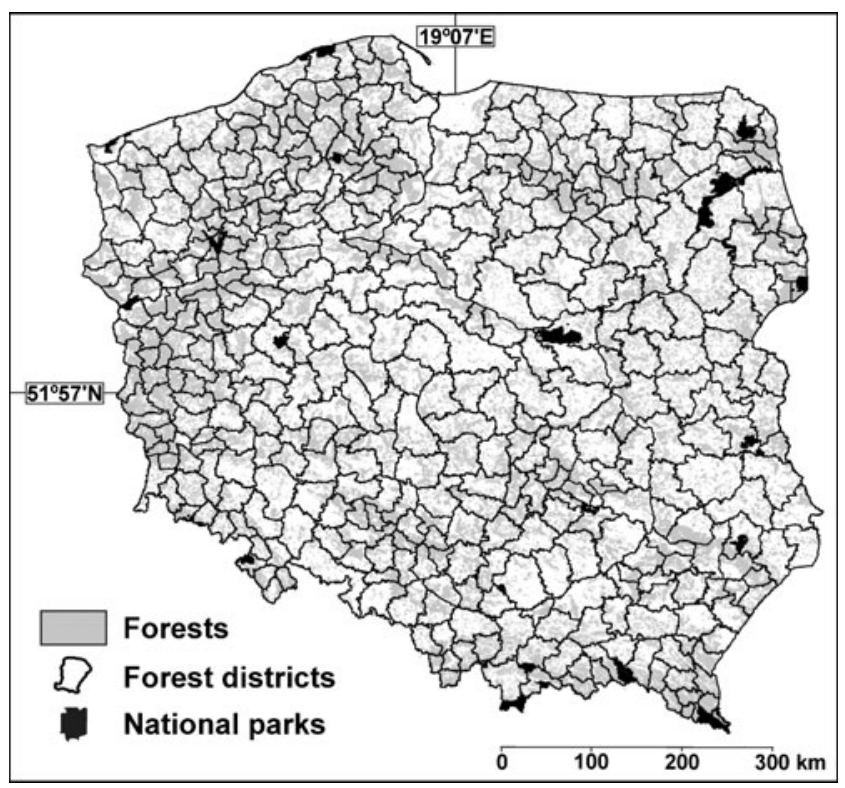

Fig. 1 Distribution of sample areas (forest districts, national parks) and forests in Poland during 1999-2003 
(Wawrzyniak et al. 2010). Red deer, wild boar, roe deer, and moose are game species. In order to increase moose numbers in Poland, a ban on hunting this species was introduced in 2001. Hunting seasons for other species generally cover autumn and early winter. The exceptions are red deer males which are hunted before and during the rutting season in late summer and autumn, roe deer males can be harvested in late spring and summer (including the rut), and wild boar males and juveniles that are shot in all months except March (Wawrzyniak et al. 2010). European bison and chamois are protected species. In the past, three alien species of ungulates were introduced to the forests of western Poland: fallow deer (Dama dama), sika deer (Cervus nippon), and mouflon (Ovis musimon). Currently, these are game species hunted in autumn and winter. North-eastern, eastern, and south-eastern regions are inhabited by viable populations of large predators such as the wolf (Canis lupus) and lynx (Lynx lynx) (Niedziałkowska et al. 2006; Jędrzejewski et al. 2008). The Carpathians harbor a population of brown bear (Ursus arctos).

\section{Material and methods}

\section{Data collection}

Official data on ungulate numbers were obtained from all State Forest districts $(n=439)$ and national parks $(n=23)$ during 1998-2003. Every year during this period, members of hunting clubs and staff of forest districts and national parks attempted to estimate ungulate numbers (red deer, roe deer, and wild boar) in managed areas. Two census methods were used. The most common were year-round observations. Every year at the beginning of spring (end of March), hunters and foresters, based on their field observations and subjective expert opinions, assessed population numbers of ungulates in hunting grounds (from 1 to 27 hunting grounds for each forest district; hunting ground area-range $15-157 \mathrm{~km}^{2}$ ). National park rangers carried out the same assessment in national parks (area-range 22-605 $\mathrm{km}^{2}$ ). Three forest districts performed drive censuses. Forest compartments to be counted using this method were randomly selected (covering about $10 \%$ of surveyed areas). During the drive census, each chosen forest compartment or block of adjoining compartments was surrounded by observers, who stationed themselves at intervals of 50 $100 \mathrm{~m}$ to maintain visual contact. The observers along three sides remained stationary, while those along the fourth side moved inward and went through the entire area. The observers (both stationary and moving) noted ungulates passing through the line of observers (on their right hand side only) and whether the ungulates were entering or leaving the closed area being censused (Pucek et al. 1975; Jedrzejewska et al. 1997; Borkowski et al. 2011). Collected observations were summed and served as estimates.

Data analyses

We computed abundance indices (number per square kilometer) for red deer, roe deer, and wild boar by dividing their official numbers (averaged over 5 years for each forest district and national park, $N=462$ ) by the area of inventory unit (forest district or national park; $\bar{x}=673.2 \mathrm{~km}^{2}, \mathrm{SD}=$ $426.3 \mathrm{~km}^{2}$, range $22-2,501 \mathrm{~km}^{2}$; Fig. 2). For each inventory unit, we also calculated the following parameters: (1) percentage of forest cover, (2) deciduous and mixed forests as a proportion of forest that is either broad-leaved or mixed, (3) arable land (proportion of nonforested land that is arable), (4) marshes (proportion of nonforested land that is marsh), (5) pastures (proportion of nonforested land that is pasture), and (6) proportion of open water. In addition, we measured the length of (7) main roads (international and national motorways), (8) secondary (regional) roads, (9) railways, and estimated (10) the number of villages (usually $<1,000$ inhabitants), (11) human population density, and (12) the mean January temperature. The variables from 1 to 6 were obtained from the Corine Land Cover 2000 database available on the website of the Institute of Geodesy and Cartography [IGC] (2011) (www.igik.edu.pl). Variables $7-$ 10 were measured on digital maps prepared by the IMAGIS Company. The human population density for the year 2002 (11) was determined using data available on the website of the Institute of Geography and Spatial Organization [IGSO], Polish Academy of Science (2011) (www.igipz.pan.pl/). January temperatures (12) were obtained from the Agroclimate model described at the Institute of Soil Science and Plant Cultivation, State Research Institute, Department of Agrometeorology and Applied Informatics [DAAI] (2011) (www.zazi.iung.pulawy.pl) for a subset of only 129 units distributed regularly across Poland. We applied interpolation to the remaining 333 units using a generalized additive model (GAM) with a bivariate nonlinear term of the latitude and longitude (Wood 2006). There was no spatial autocorrelation detectable in the residuals of the GAM, indicating that the spatial trend was adequately captured. For the analyses, we used the observed values of January temperatures where available and the GAM predictions elsewhere.

We examined collinearity between the potential explanatory variables by calculating pairwise correlation coefficients. Due to high correlations between predictor covariates $\left(R^{2}>0.4\right)$ only those judged to be most relevant and uncorrelated were considered as candidates for inclusion in the models: forest cover, deciduous and mixed forest, arable land, marsh, water, and the mean January temperature.

We were not able to include large predator (wolf and lynx) effects (expressed as predator density) and official 


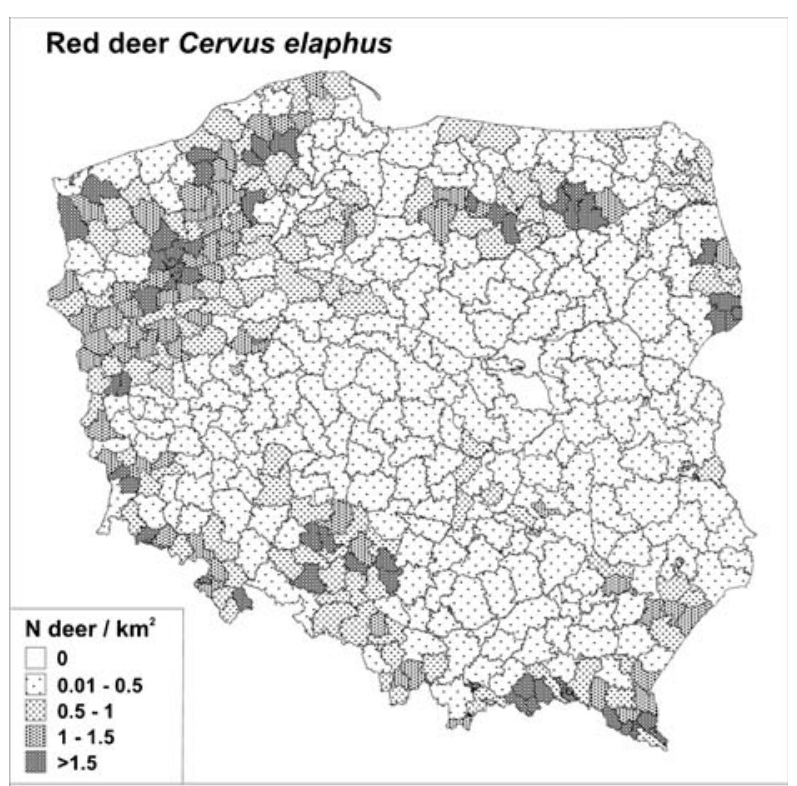

Roe deer Capreolus capreolus

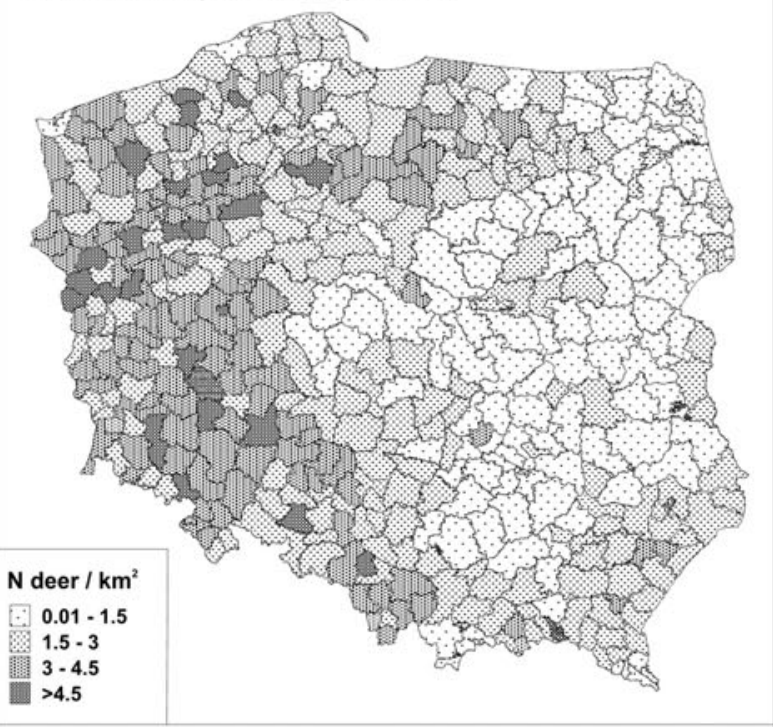

Wild boar Sus scrofa

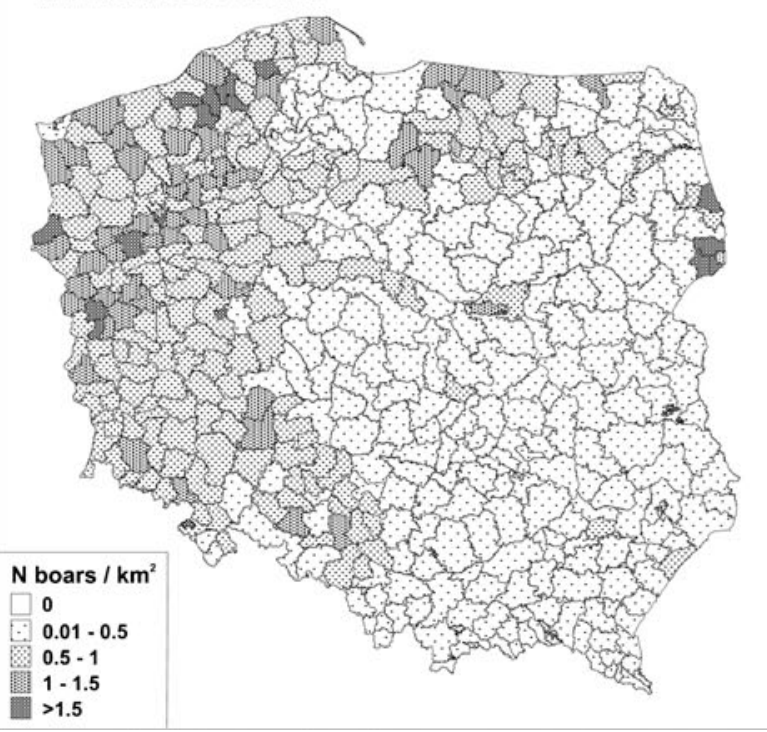

Fig. 2 Abundance indices of red deer, roe deer, and wild boar in forest districts $(n=439)$ and national parks (23) in Poland during 1999-2003

data on hunting bags in our final models. Predator effects were highly correlated with forest cover (the most informative explanatory variable). Hunting bags were estimated as a proportion of spring estimates (Wawrzyniak et al. 2010) used as dependent variable in our models.

As the response variables (red deer, roe deer, and wild boar abundance indices) presented strong right skews of the value distribution, we applied log-transformation before modeling (Sokal and Rohlf 1995). In order to determine factors effecting ungulate abundances, we used generalized additive mixed models (GAMMs) relating the abundances of the species to environmental covariates (Wood 2006). Smooth terms of the covariates were used to allow for nonlinear responses to the covariates, and spatial autocorrelation was accounted for by including a spherical correlation structure in the model (Pinheiro and Bates 2000). Given the potentially high dimensionality of the models, we opted for a forward selection procedure. Covariates were included sequentially, starting with those showing the highest correlation coefficient with the response variable. When a covariate showed evidence for a nonlinear relationship to the species abundance in an exploratory analysis with locally weighted polynomial regression (estimated degrees of freedom [edf] $>1$ ), we included it as a nonlinear term in the models using spline functions to test for nonlinearity. Covariates were retained in the model when the associated coefficient was significantly different from zero.

\section{Results}

Red deer occur throughout Poland except for two forest districts located around Warsaw, central Poland (Fig. 2). The highest indices of red deer abundance were found in the montane regions of southern Poland and in the large woodlands in western and north-eastern parts of the country. The predictor variables selected in the GAMM for red deer abundance indices were forest cover, the mean January temperature, and arable land (Table 1). The range of the spatial correlation (the distance beyond which data values were no longer spatially autocorrelated) was estimated at $1.49^{\circ}$ (about $165 \mathrm{~km}$ ). The proportion of variance explained by the final model equaled $50 \%$. Forest cover and the mean January temperature had a similar effect on deer abundance indices $(P<0.001)$, with arable land having a weaker impact $(P=0.008)$. The final model indicated a positive linear relationship between red deer abundance indices and the mean January temperature and a negative relationship with arable land (Fig. 3). Nonlinear relationship between species 
Table 1 Effects of environmental factors on red deer, roe deer, and wild boar abundance indices in Poland: results of generalized additive mixed models (GAMMs). The models include a spherical spatial correlation function for the residuals with parameters: range (the distance at which residuals are no longer autocorrelated, in decimal degrees, and in kilometers) and the nugget (correlation at distance zero). Environmental factors: forest cover, January temperature, arable land, deciduous and mixed forest, marsh, and water

\begin{tabular}{|c|c|c|c|c|c|c|c|c|c|c|}
\hline \multirow{2}{*}{$\begin{array}{l}\text { Model } \\
\text { Parameter }\end{array}$} & \multicolumn{4}{|l|}{ Linear terms } & \multicolumn{3}{|c|}{ Nonlinear terms } & \multirow[t]{2}{*}{$R_{\mathrm{adj}}^{2}$} & \multirow[t]{2}{*}{ Range } & \multirow[t]{2}{*}{ Nugge } \\
\hline & Coefficient & SE & $t$ & $P$ & edf & $F$ & $P$ & & & \\
\hline \multicolumn{11}{|l|}{ Red deer } \\
\hline Intercept & -0.41 & 0.28 & -1.49 & 0.137 & & & & 0.50 & $1.49^{\circ}(165 \mathrm{~km})$ & 0.16 \\
\hline Forest cover & & & & & 4.51 & 105.44 & $<0.001$ & & & \\
\hline January temperature & 0.27 & 0.06 & 4.68 & $<0.001$ & & & & & & \\
\hline Arable land & -0.51 & 0.18 & -2.78 & 0.006 & & & & & & \\
\hline \multicolumn{11}{|l|}{ Roe deer } \\
\hline Intercept & 0.98 & 0.13 & 7.56 & $<0.001$ & & & & 0.39 & $1.60^{\circ}(178 \mathrm{~km})$ & 0.59 \\
\hline January temperature & 0.29 & 0.03 & 9.27 & $<0.001$ & & & & & & \\
\hline Forest cover & & & & & 3.33 & 25.97 & $<0.001$ & & & \\
\hline Deciduous and mixed forest & 0.50 & 0.09 & 5.70 & $<0.001$ & & & & & & \\
\hline Arable land & 0.34 & 0.11 & 3.42 & $<0.001$ & & & & & & \\
\hline \multicolumn{11}{|l|}{ Wild boar } \\
\hline Intercept & -1.20 & 0.07 & -16.25 & $<0.001$ & & & & 0.47 & $0.04^{\circ}(4 \mathrm{~km})$ & 0.09 \\
\hline January temperature & & & & & 4.59 & 53.11 & $<0.001$ & & & \\
\hline Forest cover & & & & & 3.14 & 25.67 & $<0.001$ & & & \\
\hline Marsh & 0.35 & 0.09 & 4.05 & $<0.001$ & & & & & & \\
\hline Deciduous and mixed forest & 0.57 & 0.15 & 3.82 & $<0.001$ & & & & & & \\
\hline Water & 0.16 & 0.04 & 3.55 & $<0.001$ & & & & & & \\
\hline Arable land & & & & & 2.24 & 6.62 & $<0.001$ & & & \\
\hline
\end{tabular}

$e d f$ estimated degrees of freedom

abundance indices and forest cover showed a clear positive effect of this variable (edf=4.51, Fig. 3). Red deer abundance increased with a growing proportion of forest cover, with a slight inflection after $40 \%$ (Fig. 3).

The range of roe deer covers the whole Poland, though in central and eastern regions this species is less abundant (Fig. 2). The most parsimonious GAMMs for roe deer comprised four explanatory variables: forest cover, the mean January temperature, deciduous and mixed forest, and arable land. Spatial autocorrelation range equaled $1.60^{\circ}$ (about $178 \mathrm{~km}$ ). Predictor covariates accounted for $39 \%$ of the variation, with forest cover, the mean January temperature, and deciduous and mixed forest having the strongest impact $(P<0.001$, Table 1$)$. The results indicated a nonlinear response of roe deer abundance to forest cover (edf=3.33). Increasing forest cover positively influenced roe deer abundance indices along the entire gradient of covariate values. However, the initial growth plateaued after reaching $50 \%$ (Fig. 4). The other variables exhibited a positive linear relationship with the species abundance indices.

Wild boars inhabit the whole country, with the exception of the Tatra Mountains in the south (Fig. 2). This species was notably more common in western than in eastern Poland. The final GAMMs for wild boar included six predictor covariates: the mean January temperature, forest cover, marsh, deciduous and mixed forest, water, and arable land. Spatial autocorrelation of predictor variables was detected only to the range of $0.04^{\circ}(4 \mathrm{~km})$. The fitted model explained $47 \%$ of the variation. GAMM indicated a nonlinear relationship between the abundance indices and the mean January temperature (edf $=4.59, P<0.001)$, forest cover $(\mathrm{edf}=3.14, P<0.001)$, and arable land $(\mathrm{edf}=$ 2.24, $P<0.001)$ and a positive linear relationship for marsh $(P<0.001)$, deciduous and mixed forest $(P<0.001)$, and water $(P<0.001$, Table 1). The positive influence of increasing mean January temperature on species abundance was most conspicuous at values above $-3{ }^{\circ} \mathrm{C}$. The change in the direction of the relationship (from positive to negative) at temperatures between -5 and $4{ }^{\circ} \mathrm{C}$ might result from sparse data points (high standard errors), which indicates uncertainty in the effect of the mean January temperature at lower values (Fig. 5). Increasing forest cover had a constant and positive effect on abundance indices, reaching a plateau at $40 \%$. Marsh influence, though highly significant, could have been diluted by a small amount of data points at proportions $>10 \%$ (high standard errors). The positive effect of arable land on wild boar abundance indices declined after attaining $40 \%$ (Fig. 5). 

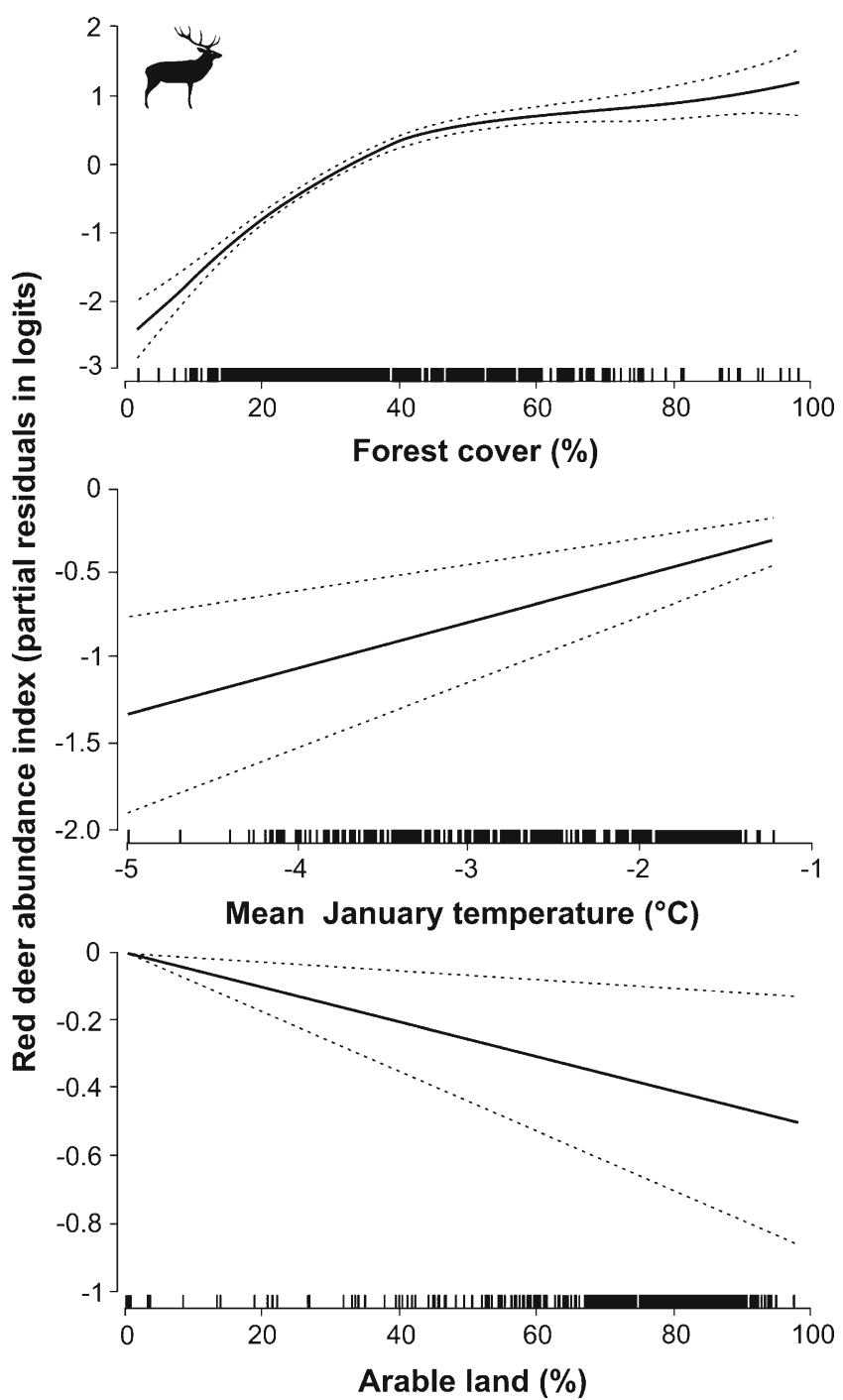

Fig. 3 Effects of environmental factors on red deer abundance indices in Poland: results of generalized additive mixed models (GAMMs). The distribution of explanatory variable values is marked with black vertical lines on the $x$-axis. The $y$-axis presents the partial residuals of the model after removing the effects of the other covariates. The slope of zero indicates a constant influence of the covariates on red deer abundance indices. Dashed lines correspond to $1 \mathrm{SE}$. Environmental factors: forest cover, January temperature, arable land, deciduous and mixed forest, marsh, and water

\section{Discussion}

As evidenced for various ungulate species (Coulson et al. 2001; Simard et al. 2010), environmental factors have a considerable influence on ungulate abundances also in Poland. Red deer numbers were strongly influenced by forest cover, which explains the high abundance of this species in southern, western, and north-eastern Poland, where large woodlands occur and forest cover often exceeds $40 \%$ (Central Statistical Office 2004). Currently, forest is considered to be an optimal habitat type for red deer in Europe, as it provides the species with various food
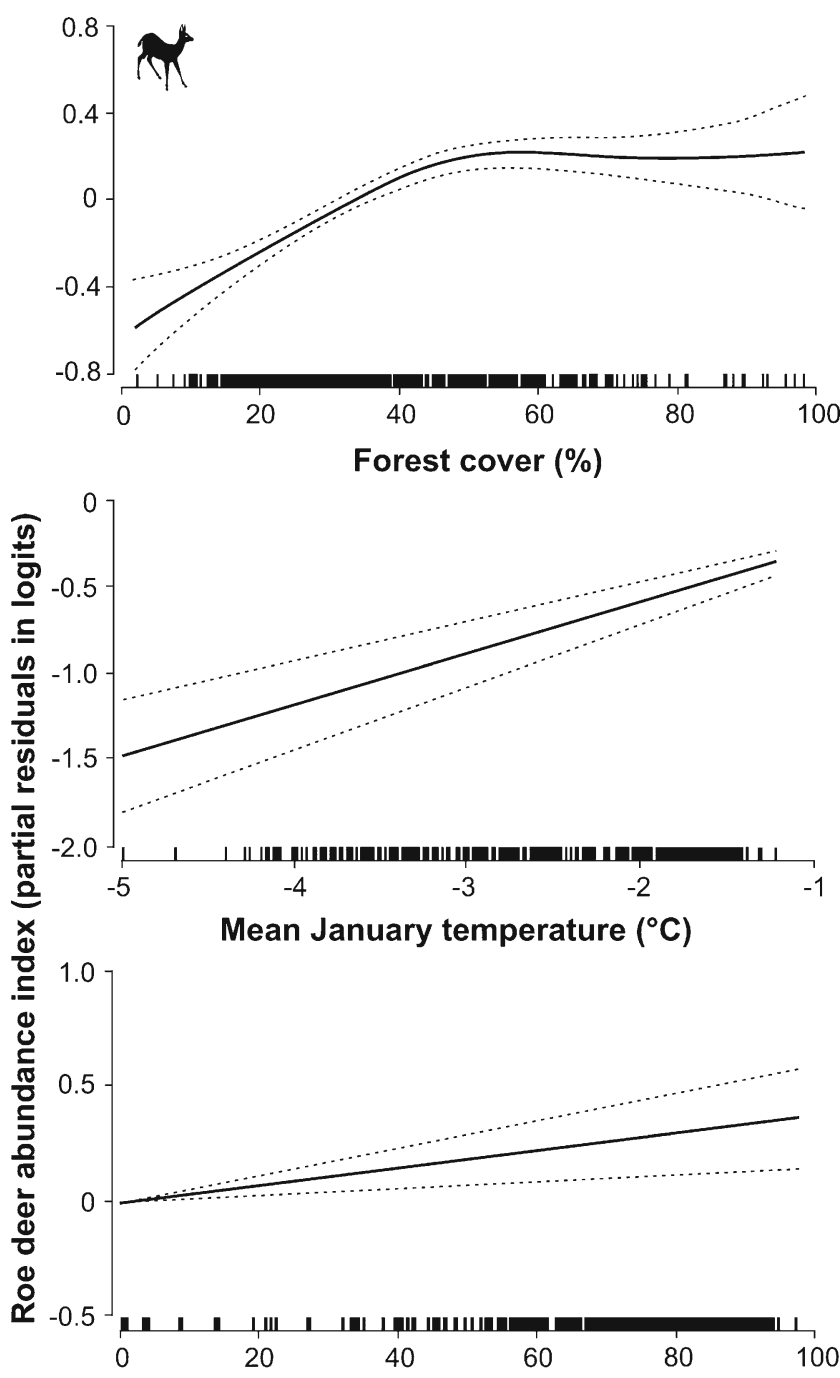

Arable land (\%)

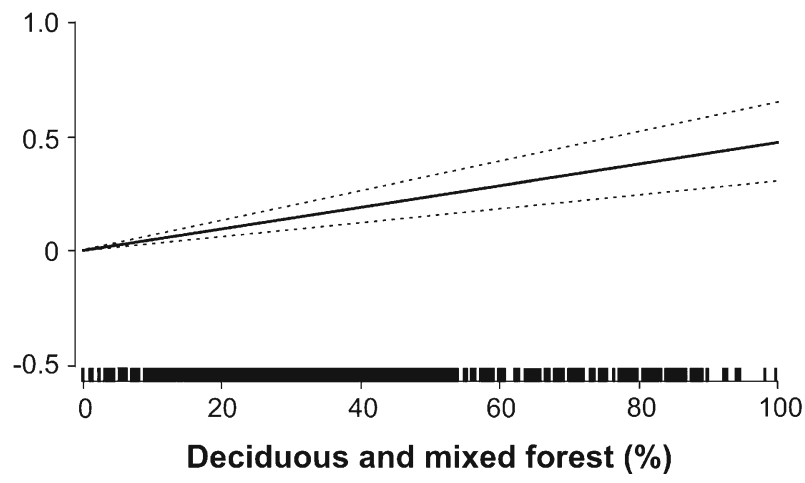

Fig. 4 Effects of environmental factors on roe deer abundance indices in Poland: results of generalized additive mixed models (GAMMs). The distribution of explanatory variable values is marked with black vertical lines on the $x$-axis. The $y$-axis presents the partial residuals of the model after removing the effects of the other covariates. The slope of zero indicates a constant influence of the covariates on roe deer abundance indices. Dashed lines correspond to 1 SE. Environmental factors: forest cover, January temperature, arable land, deciduous and mixed forest, marsh, and water 
resources (herbs, grasses, twigs, barks, acorns) throughout the year (Dzieggielewski 1970). Although previous findings (Dzięciołowski 1991; Jędrzejewska et al. 1994) reported that some red deer populations in Poland prefer deciduous woodlands, we did not find this to be the case at the larger, national scale. The lack of marshes among explanatory variables in the final model, and the negative impact of increasing arable land proportions in open areas, confirmed the low relevance of these habitat types for red deer. As shown by Dzięciołowski (1991), the importance of fields for this species is limited to the spring-summer period when animals are occasionally leaving the forest and forage on crop fields. However, the observed increase in the number and geographic distribution of the species in Poland (Central Statistical Office 2004) may enhance the role of arable land as deer habitat. This situation was observed in the lowlands of Great Britain (Putman and Moore 1998).

Climatic conditions (temperature, precipitation, and snow depth) were found to influence the population demography and dynamics of ungulates by affecting plant productivity or, more directly, by forcing energetic demands or behavioral restraints (Saether 1997; Martinez-Jauregui et al. 2009). Loison and Langvatn (1998) analyzed red deer densities in Norway and found that deep snow and high wind speed were correlated with low red deer densities. In the case of Polish red deer populations, the mean January temperature negatively affected population dynamics directly through winter mortality (Okarma et al. 1995). Our study confirmed the positive influence of an increasing mean January temperature on red deer abundance. As temperatures in Poland exhibit a longitudinal gradient — decreasing from west to east with montane regions in the south being an exception (elevation temperature zones; Lorenc 2005) - the highest red deer numbers were recorded in units located in the western and north-western parts of the country.

The roe deer is regarded as the ungulate with the largest ecological plasticity (Cagnacci et al. 2011) and we therefore expected this species to be less affected by environmental factors. Our model indicated forest cover to be the most influential factor of roe deer abundance. Areas with forest cover above $50 \%$ held the highest abundances of roe deer. The positive effect of increasing forest cover on roe deer abundance was also found by Melis et al. (2009) on a European scale. Roe deer, the species typically considered to be adapted to woodlands (Hewison et al. 1998), selects forests for cover (Mysterud and Ostbye 1999) and forage (Van Moorter et al. 2009). The species is a generalist, but also a highly selective herbivore that feeds on a variety of plant species (Duncan et al. 1998) and prefers forests rich in multispecies herb and bush layers (Barancekova 2004). Pucek et al. (1975) reported a higher density of roe deer in Polish deciduous and mixed forests, where most diverse ground vegetation occurs. The same positive influence of increasing proportion of deciduous and mixed forest stands was confirmed by our final model. In Great Britain, coniferous forests are favored by roe deer only when they provide high availability of clear-cuts and young plantations (Putman 1994).

The growth in proportion of arable land had a positive effect on roe deer numbers. Though roe deer predominantly inhabited forests in the past, they adapted to agricultural habitats following broad-scale deforestation (Hewison et al. 1998). Agricultural landscapes facilitate roe deer by providing high quality food (Hewison et al. 2009; Abbas et al. 2011). Hence, nowadays there are roe deer herds not depending on forest habitats (Fruziński et al. 1982; Hewison et al. 2001; Sönnichsen et al. 2013).

An increase in mean January temperature positively affected roe deer abundances. Holand et al. (1998) listed heavy foot loading, small body size, and low brisket height as factors challenging roe deer during adverse winter conditions. Okarma et al. (1995) in Poland and Kiili (1991) in Estonia found a relationship between severe winter weather and the number of adult mortalities from exhaustion, hunger, and predation. Similar to red deer, roe deer have the most favorable weather conditions in western Poland, where the species is most abundant.

Wild boar abundance indices were profoundly influenced by forest cover. Areas where forest cover exceeds $40 \%$ had the highest abundances of the species. A similar relationship was confirmed by Virgos (2002) in Spain where wild boars occurred more frequently in areas comprising larger forest fragments. The positive influence of forest cover on wild boar abundance is primarily related to food supply and shelter (Massei et al. 1996; Schley and Roper 2003). Herrero et al. (2008) showed the multidirectional importance of shelter availability on the performance of two Iberian wild boar populations, where shelter influenced growth, productivity, and life expectancy. Though the wild boar is considered an omnivorous species, most of its diet (up to $90 \%$ ) consists of plants (Poland: Genov 1981a; Western Europe: Schley and Roper 2003). Our model indicated a positive influence of increasing proportions of deciduous and mixed forests on species abundance. In Poland, such forest habitats are dominated by heavy seed species: oak and/or beech. Every 3-8 years (mast years), these trees produce large amounts of seeds that constitute autumnwinter food for wild boars (Jędrzejewska et al. 1997). Jędrzejewska and Jędrzejewski (1998) documented a higher wild boar reproduction rate and better survival of piglets in the years following masting of oaks in the Białowieża Primeval Forest (Poland). Apart from seeds, deciduous forests supply wild boar with abundant food on the forest floor in the spring and summer (Faliński 1986) and high availability of edible starchy tubers and bulbs during winter (North Carolina and Tennessee, USA: Howe and Bratton 
Fig. 5 Effects of

environmental factors on wild boar abundance indices in Poland: results of generalized additive mixed models (GAMMs). The distribution of explanatory variable values is marked with black vertical lines on the $x$-axis. The $y$-axis presents the partial residuals of the model after removing the effects of the other covariates. The slope of zero indicates a constant influence of the covariates on wild boar abundance indices. Dashed lines correspond to $1 \mathrm{SE}$. Environmental factors: forest cover, January temperature, arable land, deciduous and mixed forest, marsh, and water

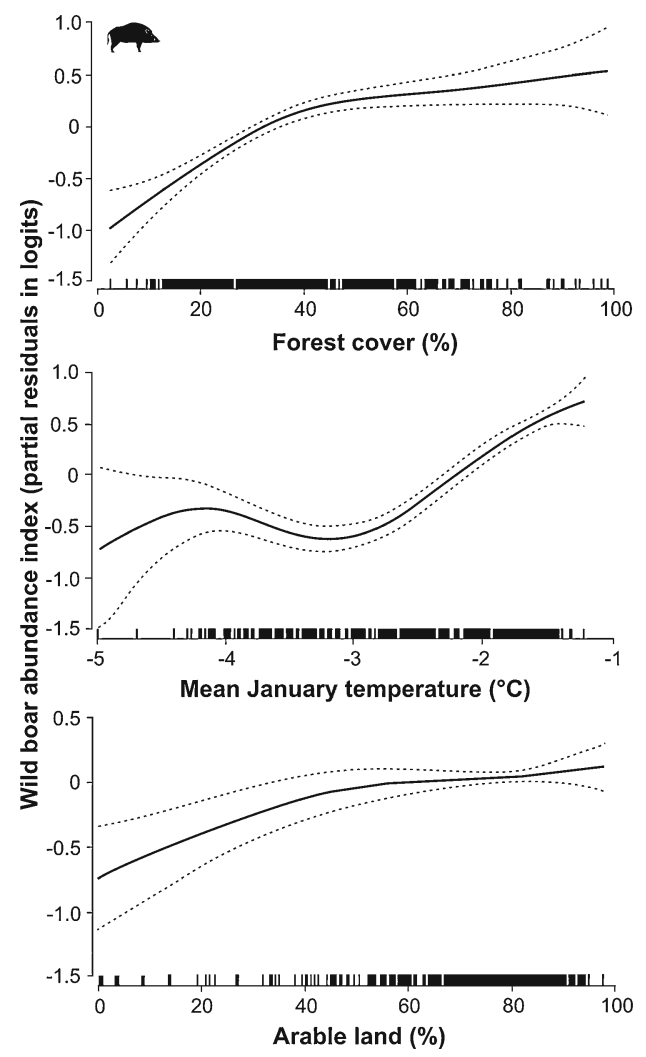

1976). Moreover, the soil of deciduous forests contains a large biomass of various forms of invertebrates (France: Baubet et al. 2003).

The positive influence of increasing proportion of marshes and water on wild boar abundance is generally explained by the same factors. Wild boars visit marshes and habitats connected with water bodies for feeding and wallowing (mud bathing) (France: Dardaillon 1987; Mediterranean wetlands: Vanschoenwinkel et al. 2008). Gimenez-Anaya et al. (2008) reported that up to $24 \%$ of a wild boar's diet consisted of roots and bulbs of aquatic vegetation in a coastal Mediterranean wetland. High reeds and sedges serve as perfect shelter against unfavorable weather conditions, predators, and hunting pressure. The importance of habitats connected with water is highly seasonal and most important in summer when animals experience high temperatures and need a constant water supply for thermoregulation (Bracke 2011).

Past human pressures on deciduous and mixed forest (deforestation) resulted in a decreasing proportion of these forest habitats in Poland (presently approximately $25 \%$ of the forest cover). This has resulted in a decline in the amount of optimal wild boar habitat and changed animal habitat utilization towards a more intensive use of arable land (Genov 1981b). Our model also confirmed the importance of arable land to wild boars. In Poland, crop plants (maize, wheat, potatoes) can constitute up to $81 \%$ of their summer diet (Fruziński 1992). Interestingly, the proportion of crops in a wild boar's diet drops substantially during mast years, resulting in lower damage levels on farmlands (Genov 1981a). Wild boar use farmlands mainly in the growing season (spring-autumn) but always prefer foraging close to shelters such as forest belts or high vegetation patches (Poland: Fonseca 2008; Japan: Honda 2009).

In wild boar populations, the major cause of densityindependent mortality is severe winter conditions (Okarma et al. 1995; Melis et al. 2006). Deep snow and frozen soil constrain movements and foraging and disable rooting and the ability to obtain food (Melis et al. 2006). In addition, prolonged and unfavorable winter conditions (low temperature in early spring) directly influenced the survival of the newborn piglets in Switzerland (Geisser and Reyer 2005). Our data are concordant with previous reports on the negative impact of low winter temperatures on wild boars. The highest abundances of the species were found in western Poland where wild boar populations experience milder winter conditions than the eastern or southern (montane) populations.

We conclude that our findings may be applied in predicting future ungulate demographic and distribution trends in Poland, especially under ongoing changes directly connected with global warming and increasing forest cover. We expect that milder winter conditions will facilitate performance of these ungulates directly, which will result in the growth of their numbers. In addition, increasing temperatures will cause changes in ungulate habitats. In recent 
decades, a shift in tree species composition has been observed in European forests with coniferous habitats being replaced by mixed and deciduous forests (Sykes et al. 1996). We presume that this process will increase ungulate food supply considerably and augment their populations. In Poland, all these changes will coincide with an increase in forest cover due to natural succession processes and the implementation of a national program of forest cover growth, which will presumably cause an additional increase in ungulate numbers.

Acknowledgments Special thanks to State Forest districts and national parks for providing official data on ungulate numbers and Prof. Włodzimierz Jędrzejewski and Michał Mazurkiewicz for their help in data collection and processing of the data files. The work of Thomas Cornulier during data analysis was supported by a Marie Curie Transfer of Knowledge Fellowship BIORESC of the European Community's 6th Framework Programme under contract number MTKDCT-2005-029957. The project was financed by The Polish Ministry of Sciences and Higher Education (grant no. N N304 094034).

Open Access This article is distributed under the terms of the Creative Commons Attribution License which permits any use, distribution, and reproduction in any medium, provided the original author(s) and the source are credited.

\section{References}

Abbas F, Morellet N, Hewison AJM, Merlet J, Cargnelutti B, Lourtet B, Angibault JM, Daufresne T, Aulagnier S, Verheyden H (2011) Landscape fragmentation generates spatial variation of diet composition and quality in a generalist herbivore. Oecologia 167:401-411

Ballard WB, Miller SD (1990) Effects of reducing brown bear density on moose calf survival in south-central Alaska. Alces 26:9-13

Barancekova M (2004) The roe deer diet: is floodplain forest optimal habitat? Folia Zool 53:285-292

Baubet E, Ropert-Coudert Y, Brandt S (2003) Seasonal and annual variations in earthworm consumption by wild boar (Sus scrofa scrofa L.). Wildl Res 30:179-186

Borkowski J, Palmer SCF, Borowski Z (2011) Drive counts as a method of estimating ungulate density in forests: mission impossible? Acta Theriol 56:239-253

Boutin S (1992) Predation and moose population dynamics: a critique. J Wildl Manag 56:116-127

Bracke MBM (2011) Review of wallowing in pigs: description of the behaviour and its motivational basis. Appl Anim Behav Sci 132:1-13

Brown GS (2011) Patterns and causes of demographic variation in a harvested moose population: evidence for the effects of climate and density-dependent drivers. J Anim Ecol 80:1288-1298

Cagnacci F, Focardi S, Heurich M, Stache A, Hewison AJM, Morellet N, Kjellander P, Linnell JDC, Mysterud A, Neteler M, Delucchi L, Ossi F, Urbano F (2011) Partial migration in roe deer: migratory and resident tactics are end points of a behavioural gradient determined by ecological factors. Oikos 120:1790-1802

Capurro AF, Gatto M, Tosi G (1997) Delayed and inverse density dependence in a chamois population of the Italian Alps. Ecography 20:37-47

Central Statistical Office (2004) Forestry. Central Statistical Office, Warsaw [In Polish]

Central Statistical Office (2011a) Concise statistical yearbook of Poland. Central Statistical Office, Warsaw [In Polish]
Central Statistical Office (2011b) Demographic yearbook of Poland. Central Statistical Office, Warsaw [In Polish]

Central Statistical Office (2011c) Forestry. Central Statistical Office, Warsaw [In Polish]

Clutton-Brock TH, Major M, Guinness FE (1985) Population regulation in male and female red deer. J Anim Ecol 54:831-846

Clutton-Brock TH, Albon SD, Guinness FE (1987a) Interactions and maternal characteristics affecting fecundity and juvenile survival in red deer. J Anim Ecol 56:857-971

Clutton-Brock TH, Major M, Albon SD, Guinness FE (1987b) Early development and population-dynamics in red deer 1. Densitydependent effects on juvenile survival. J Anim Ecol 56:53-67

Coulson T, Milner-Gulland EJ, Clutton-Brock TH (2000) The relative roles of density and climatic variation on population dynamics and fecundity rates in three contrasting ungulate species. P Roy Soc Lond B Biol 267:1771-1779

Coulson TE, Catchpole A, Albon SD, Morgan BJT, Pemberton JM, Clutton-Brock TH, Crawley MJ, Grenfell BT (2001) Age, sex, density, winter weather, and population crashes in Soay sheep. Science 292:1528-1531

Dardaillon M (1987) Seasonal feeding-habits of the wild boar in a Mediterranean wetland, the Camargue (Southern France). Acta Theriol 32:389-401

Duncan P, Tixier H, Hofman RR, Lechner-Doll M (1998) Feeding strategies and the physiology of digestion in roe deer. In: Andersen R, Duncan P, Linnell JDC (eds) The European roe deer: the biology of success. Scandinavian University Press, Oslo, pp 91-116

Dzięciołowski RM (1991) Ecological niches of five big ungulates in a forest tract. Folia For Pol Ser A 33:56-70

Dzięgielewski S (1970) Jeleń. Monografia przyrodniczo-łowiecka. Państwowe Wydawnictwo Rolnicze i Leśne, Warszawa [In Polish]

Faliński FB (1986) Vegetation dynamics in temperate lowland primeval forest. Dr W. Junk, Dortrecht

Fonseca C (2008) Winter habitat selection by wild boar Sus scrofa in southeastern Poland. Eur J Wildl Res 54:361-366

Forchhammer MC, Stenseth NC, Post E, Langvatn R (1998) Population dynamics of Norwegian red deer: densitydependence and climatic variation. P Roy Soc Lond B Biol 265:341-350

Fruziński B (1992) Dzik. Cedrus, Warszawa [In Polish]

Fruziński B, Kałuziński J, Baksalary J (1982) Weight and body measurements of forest and field roe deer. Acta Theriol 27:479-488

Gaillard JM, Delorme D, Boutin JM, Vanlaere G, Boisaubert B, Pradel R (1993) Roe deer survival patterns - a comparative analysis of contrasting populations. J Anim Ecol 62:778-791

Geisser H, Reyer HU (2005) The influence of food and temperature on population density of wild boar Sus scrofa in the Thurgau (Switzerland). J Zool 267:89-96

Genov P (1981a) Food composition of wild boar in northeastern and western Poland. Acta Theriol 26:185-205

Genov P (1981b) The distribution of wild boar (Sus scrofa L.) in Eurasia and its adaptation to the feeding condition. Z Jagdwiss 27:221-231

Gimenez-Anaya A, Herrero J, Rosell C, Couto S, Garcia-Serrano A (2008) Food habits of wild boars (Sus scrofa) in a Mediterranean coastal wetland. Wetlands 28:197-203

Hayes RD, Farnell R, Ward RMP, Carey J, Dehn M, Kuzyk GW, Baer AM, Gardner CL, O'Donoghue M (2003) Experimental reduction of wolves in the Yukon: ungulate responses and management implications. Wildl Monogr 152:1-35

Hegel TM, Mysterud A, Huettmann F, Stenseth NC (2010) Interacting effect of wolves and climate on recruitment in a northern mountain caribou population. Oikos 119:1453-1461

Herrero J, Garcia-Serrano A, Garcia-Gonzalez R (2008) Reproductive and demographic parameters in two Iberian wild boar Sus scrofa populations. Acta Theriol 53:355-364 
Hewison AJM, Vincent JP, Reby D (1998) Social organisation of European roe deer. In: Andersen R, Duncan P, Linnell JDC (eds) The European roe deer: the biology of success. Scandinavian University Press, Oslo, pp 189-219

Hewison AJM, Vincent JP, Joachim J, Angibault JM, Cargnelutti B, Cibien C (2001) The effects of woodland fragmentation and human activity on roe deer distribution in agricultural landscapes. Can J Zool 79:679-689

Hewison AJM, Morellet N, Verheyden H, Daufresne T, Angibault JM, Cargnelutti B, Merlet J, Picot D, Rames JL, Joachim J, Lourtet B, Serrano E, Bideau E, Cebe N (2009) Landscape fragmentation influences winter body mass of roe deer. Ecography 32:10621070

Holand Ø, Mysterud A, Wannag A, Linnell JDC (1998) Roe deer in northern environments: physiology and behavior. In: Andersen R, Duncan P, Linnell JDC (eds) The European roe deer: the biology of success. Scandinavian University Press, Oslo, pp 117-137

Honda T (2009) Environmental factors affecting the distribution of the wild boar, sika deer, Asiatic black bear and Japanese macaque in central Japan, with implications for human-wildlife conflict. Mamm Study 34:107-116

Hone J, Clutton-Brock TH (2007) Climate, food, density and wildlife population growth rate. J Anim Ecol 76:361-367

Howe TD, Bratton SP (1976) Winter rooting activity of the European wild boar in the Great Smoky Mountains National Park. Castanea 41:256-264

Institute of Geodesy and Cartography [IGC] (2011) IGC homepage. http://www.igik.edu.pl. Accessed 7 Sep 2011

Institute of Geography and Spatial Organization [IGSO], Polish Academy of Science (2011) IGSO homepage. http://www.igipz.pan.pl. Accessed 10 Oct 2011

Institute of Soil Science and Plant Cultivation, State Research Institute. Department of Agrometeorology and Applied Informatics [DAAI] (2011) DAAI homepage. http://www.zazi.iung.pulawy.pl. Accessed 15 Oct 2011.

Jędrzejewska B, Jędrzejewski W (1998) Predation in vertebrate communities. The Białowieża Primeval Forest as a case study. Springer, Berlin

Jędrzejewska B, Jędrzejewski W (2005) Large carnivores and ungulates in European temperate forest ecosystems: bottom-up and top-down control. In: Ray JC, Redford KH, Steneck RS, Berger $\mathrm{J}$ (eds) Large carnivores and the conservation of biodiversity. Island, Washington, pp 230-246

Jędrzejewska B, Okarma H, Jędrzejewski W, Miłkowski L (1994) Effects of exploitation and protection on forest structure, ungulate density and wolf predation in Białowieża Primeval Forest, Poland. J Appl Ecol 31:664-676

Jędrzejewska B, Jędrzejewski W, Bunevich AN, Miłkowski L, Krasiński ZA (1997) Factors shaping population densities and increase rates of ungulates in Białowieża Primeval Forest (Poland and Belarus) in the 19th and 20th centuries. Acta Theriol 42:399-451

Jędrzejewski W, Jędrzejewska B, Zawadzka B, Borowik T, Nowak S, Mysłajek RW (2008) Habitat suitability model for Polish wolves based on long-term national census. Anim Conserv 11:377-390

Jorgenson JT, Festa-Bianchet M, Lucherini M, Wishart WD (1993) Effects of body size, population density, and maternal characteristics on age at first reproduction in bighorn ewes. Can J Zool 71:2509-2517

Kiili J (1991) Influences of climatic factors on roe deer population dynamics in Estonia. In: Bobek B, Regelin W (eds) Global trends in wildlife management, transactions 18th IUGB Congress, Kraków 1987. Świat Press, Kraków-Warszawa, pp 579-582

Langvatn R, Albon SD, Burkey T, Clutton-Brock TH (1996) Climate, plant phenology and variation in age of first reproduction in a temperate herbivore. J Anim Ecol 65:653-670
Larsen DG, Gauthier DA, Markel RL (1989) Causes and rate of moose mortality in the southwest Yukon. J Wildl Manag 53:548-557

Loison A, Langvatn R (1998) Short- and long-term effects of winter and spring weather on growth and survival of red deer in Norway. Oecologia 116:489-500

Lorenc H (2005) Atlas klimatu Polski. Instytut Meteorologii Gospodarki Wodnej, Warszawa [In Polish]

Martinez-Jauregui M, San Miguel-Ayanz A, Mysterud A, RodriguezVigal C, Clutton-Brock TH, Langvatn R, Coulson T (2009) Are local weather, NDVI and NAO consistent determinants of red deer weight across three contrasting European countries? Global Change Biol 15:1727-1738

Massei G, Genov PV, Staines BW (1996) Diet, food availability and reproduction of wild boar in a Mediterranean coastal area. Acta Theriol 41:307-320

Melis C, Szafrańska PA, Jędrzejewska B, Bartoń K (2006) Biogeographical variation in the population density of wild boar (Sus scrofa) in western Eurasia. J Biogeogr 33:803-811

Melis C, Jędrzejewska B, Apollonio M, Bartoń KA, Jędrzejewski W, Linnell JDC, Kojola I, Kusak J, Adamic M, Ciuti S, Delehan I, Dykyy I, Krapinec K, Mattioli L, Sagaydak A, Samchuk N, Schmidt K, Shkvyrya M, Sidorovich VE, Zawadzka B, Zhyla S (2009) Predation has a greater impact in less productive environments: variation in roe deer, Capreolus capreolus, population density across Europe. Glob Ecol Biogeogr 18:724-734

Messier F (1994) Ungulate population models with predation: a case study with the North American moose. Ecology 75:478-488

Milner JM, Elston DA, Albon SD (1999) Estimating the contributions of population density and climatic fluctuations to interannual variation in survival of Soay sheep. J Anim Ecol 68:1235-1247

Mysterud A, Ostbye E (1999) Cover as a habitat element for temperate ungulates: effects on habitat selection and demography. Wildl Soc B 27:385-394

Niedziałkowska M, Jędrzejewski W, Mysłajek RW, Nowak S, Jędrzejewska B, Schmidt K (2006) Environmental correlates of Eurasian lynx occurrence in Poland-large scale census and GIS mapping. Biol Conserv 133:63-69

Okarma H, Jędrzejewska B, Jędrzejewski W, Krasiński ZA, Miłkowski L (1995) The roles of predation, snow cover, acorn crop, and man-related factors on ungulate mortality in Białowieża Primeval Forest, Poland. Acta Theriol 40:197-217

Pettorelli N, Pelletier F, von Hardenberg A, Festa-Bianchet M, Cote SD (2007) Early onset of vegetation growth vs rapid green-up: impacts on juvenile mountain ungulates. Ecology 88:381-390

Pinheiro JC, Bates DM (2000) Mixed-effects models in S and S-PLUS. Springer, New York

Post E, Stenseth NC (1999) Climatic variability, plant phenology, and northern ungulates. Ecology 80:1322-1339

Pucek Z, Bobek B, Łabudzki L, Miłkowski L, Morow K, Tomek A (1975) Estimates of density and number of ungulates. Pol Ecol Stud 1:121-135

Putman RJ (1994) Damage by deer in coppice woodlands: an analysis of factors affecting the severity of damage and options for management. Q J Forest 88:45-54

Putman RJ, Moore NP (1998) Impact of deer in lowland Britain on agriculture, forestry and conservation habitats. Mamm Rev 28:141-164

Saether BE (1997) Environmental stochasticity and population dynamics of large herbivores: a search for mechanisms. Trends Ecol Evol 12:143-149

Schley L, Roper TJ (2003) Diet of wild boar Sus scrofa in Western Europe, with particular reference to consumption of agricultural crops. Mamm Rev 33:43-56

Simard MA, Coulson T, Gingras A, Cote SD (2010) Influence of density and climate on population dynamics of a large herbivore under harsh environmental conditions. J Wildl Manag 74:1671-1685 
Sims M, Elston DA, Larkham A, Nussey DH, Albon SD (2007) Identifying when weather influences life-history traits of grazing herbivores. J Anim Ecol 76:761-770

Sokal RR, Rohlf FJ (1995) Biometry, 3rd edn. Freeman, New York

Sönnichsen L, Bokje M, Marchal J, Hofer H, Jędrzejewska B, KramerSchadt S, Ortmann S (2013) Behavioural responses of European roe deer to temporal variation in predation risk. Ethology 119:233-243

Sykes MT, Prentice IC, Cramer W (1996) A bioclimatic model for the potential distributions of north European tree species under present and future climates. J Biogeogr 23:203-233

Van Moorter B, Gaillard JM, McLoughlin PD, Delorme D, Klein F, Boyce MS (2009) Maternal and individual effects in selection of bed sites and their consequences for fawn survival at different spatial scales. Oecologia 159:669-678

Vanschoenwinkel B, Waterkeyn A, Vandecaetsbeek T, Pineau O, Grillas P, Brendonck L (2008) Dispersal of freshwater invertebrates by large terrestrial mammals: a case study with wild boar (Sus scrofa) in Mediterranean wetlands. Freshwater Biol 53:2264-2273

Virgos E (2002) Factors affecting wild boar (Sus scrofa) occurrence in highly fragmented Mediterranean landscapes. Can J Zool 80:430 435

Wawrzyniak P, Jędrzejewski W, Jędrzejewska B, Borowik T (2010) Ungulates and their management in Poland. In: Apollonio M, Andersen R, Putman R (eds) European ungulates and their management in the 21 st century. Cambridge University Press, Cambridge, pp 223-242

Willisch CS, Bieri K, Struch M, Franceschina R, Schnidrig-Petrig R, Ingold P (2013) Climate effects on demographic parameters in an unhunted population of Alpine chamois (Rupicapra rupicapra). $\mathrm{J}$ Mammal 94:173-182

Wood S (2006) Generalized additive models: an introduction with R. Champman \& Hall/CRC, Boca Raton 